\title{
Reclassification of Bisgaard taxon 33, with proposal of Volucribacter psittacicida gen. nov., sp. nov. and Volucribacter amazonae sp. nov. as new members of the Pasteurellaceae
}

\author{
Henrik Christensen, Magne Bisgaard, Bent Aalbæk \\ and John Elmerdahl Olsen
}

Correspondence Henrik Christensen hech@kvl.dk

\author{
Department of Veterinary Microbiology, the Royal Veterinary and Agricultural University, \\ Stigbøjlen 4, 1870 Frederiksberg C, Denmark
}

High density of pet birds under confined rearing facilities might change the parasite-host balance and result in disease. In a previous investigation, it was found that some organisms isolated from these birds could not be classified as any named species and consequently they remained as unnamed taxa of the Pasteurellaceae (Bisgaard et al., 1999). Accurate diagnosis of bacteria isolated from diseased pet birds is a prerequisite for disease treatment and prevention, in addition to health improvement. Especially with members of the Pasteurellaceae, identification has remained a problem, because many groups are weakly characterized or are at most classified as unnamed taxa. This might result in uncertain or misleading identification (Bisgaard, 1993; Christensen et al., 2002b, 2003b).

Twelve strains, all originating from psittacine bird species, were shown to represent a new taxon tentatively named Bisgaard taxon 33 on the basis of phenotypic

Published online ahead of print on 28 November 2003 as DOI 10.1099/ijs.0.02797-0.

The GenBank/EMBL/DDBJ accession numbers for the 16S rDNA sequences of strains Gerl. 236/81 ${ }^{\top}, 146 / S 8 / 89^{\top}$ and B96/5 are AY216868-AY216870 and those for strains 94, 101 and 103 are AF487722-AF487724, respectively. characterization and ribotyping (Bisgaard et al., 1999). Ribotyping of selected strains showed that taxon 33 strains formed a separate cluster (Bisgaard et al., 1999). The original publication included isolates obtained from lesions of lungs, trachea, air sac, liver, spleen and eyes of parrots. Since this publication, 13 additional strains have been obtained and investigated and been found to be both phenotypically and genotypically similar to taxon 33 .

The present study aimed at a final classification of Bisgaard taxon 33, with the proposal of a new genus within the Pasteurellaceae.

\section{Phenotypic characterization}

In addition to the 12 strains already characterized phenotypically, nine of which were ribotyped in the previous publication (Bisgaard et al., 1999), 13 further strains were phenotyped according to Bisgaard et al. (1991). The total number of strains investigated originated from parrots (15), budgerigars (7), parakeets (2) and a chicken. With the exception of a single isolate, all isolates were obtained from lesions, mostly from the respiratory tract or septicaemia. Isolates have so far only been obtained in European countries, including Belgium, Denmark and Germany. 
Common phenotypic characteristics of the 25 strains classified with Bisgaard taxon 33 and proposed as Volucribacter gen. nov. included positive reactions for methyl red, nitrate, porphyrin and acid production without gas from $(-)$-D-ribose, (-)-D-fructose, (+)-D-galactose, $(+)$-Dglucose, (+)-D-mannose, sucrose and raffinose, whereas negative reactions were observed for symbiotic growth, urease, ornithine decarboxylase, $\alpha$-glucosidase (PNPG; 4 -nitrophenyl $\alpha$-D-glucopyranoside) and fermentation of (-)-D-mannitol, (-)-D-sorbitol and trehalose. A full list of the 81 phenotypic characters investigated is given with the description of the genus.

Characters that are variable within the genus are listed with Table 1 and allow two biovars to be distinguished. Biovar 1, including 22 strains, is negative for the ONPG (o-nitrophenyl D-galactopyranoside) test and does not produce acid from (-)-L-fucose, maltose or dextrin, whereas biovar 2, including three strains, is positive for these characters.

Biovar 2 was defined on the basis of three phenotypic variants. Strain $146 / S 8 / 89^{\mathrm{T}}$ can be described as a mesoinositol-, ONPG-, maltose-, melibiose-, dextrin- and $\alpha$ galactosidase-positive variant of Volucribacter, while strain

Table 1. Phenotypic variation observed for isolates of Volucribacter gen. nov. (Bisgaard taxon 33)

Strains examined: V. psittacicida sp. nov., 22 strains isolated from parrot, budgerigar, parakeet and chicken in Belgium, Denmark and Germany; V. amazonae sp. nov., three strains isolated from parrot and parakeet in Belgium, Denmark and Germany. Characters are scored as:,$+ 90 \%$ or more of strains positive within 1-2 days; (+), $90 \%$ or more of strains positive within 3-14 days; -, fewer than $10 \%$ of strains positive within 14 days; d, $11-89 \%$ of strains positive. Numbers of strains positive for particular characters are given in parentheses.

\begin{tabular}{|lcc|}
\hline Character & $\begin{array}{c}\text { V. psittacicida } \\
\text { (biovar 1) }\end{array}$ & $\begin{array}{c}\text { V. amazonae } \\
\text { (biovar 2) }\end{array}$ \\
\hline Catalase & $\mathrm{d}(11)$ & + \\
Oxidase & $\mathrm{d}(17)$ & $\mathrm{d}(2)$ \\
Phosphatase & $+/$ weak & + \\
Glycerol & $(+)(21)$ & $\mathrm{d}(2)$ \\
$(+)$-L-Arabinose & - & $\mathrm{d}(1)$ \\
$(-)$-D-Arabinose & $-(1)$ & $\mathrm{d}(1)$ \\
$(+)$-D-Xylose & $-(1)$ & $\mathrm{d}(1)$ \\
meso-Inositol & $-(1)$ & $+/(+)$ \\
$(-)$-L-Fucose & - & $(+)$ \\
Lactose & - & $\mathrm{d}(1)$ \\
ONPG & - & + \\
Maltose & - & $\mathrm{d}(2)$ \\
$(+)$-D-Melibiose & - & $+/(+)$ \\
Dextrin & - & $\mathrm{d}(2)$ \\
$\alpha$-Galactosidase & $-(1)$ & \\
\hline
\end{tabular}

B96/5 represents an (+ )-L-arabinose-, meso-inositol-, ONPG, maltose- and dextrin-positive variant. Finally, strain 64 can be regarded as a $(+)$-D-xylose-, meso-inositol-, lactose-, ONPG-, maltose-, melibiose-, dextrin- and $\alpha$-galactosidasepositive variant.

The existence of two biovars indicated the existence of two species within Volucribacter, as also indicated by the lower 16S rRNA gene sequence similarities between the biovars than within them and the low degree of DNADNA hybridization (see below).

The phenotypic characters indicate that Volucribacter is a member of the Pasteurellaceae as defined by Olsen et al. (2004) and previously suggested by Bisgaard et al. (1999). Between two and four phenotypic characters separate the genus Volucribacter from other genera of the Pasteurellaceae (Table 2). Data for the other genera and genus-like groups of Pasteurellaceae were obtained from Angen et al. (1999) (Mannheimia), Mutters et al. (2004) (Pasteurella sensu stricto), Osawa \& Stackebrandt (2004) (Lonepinella), Foster \& Collins (2004) (Phocoenobacter), Kilian (2004) (Haemophilus sensu stricto), Christensen et al. (2003a) (Gallibacterium), Angen et al. (2003) (Histophilus somni) and Christensen \& Bisgaard (2004) (Actinobacillus sensu stricto). Only differences in (-)-D-mannitol and $\alpha$-glucosidase separate taxon 33 from Gallibacterium. However, most isolates of Gallibacterium are $\beta$-haemolytic and trehalose-positive, while taxon 33 is negative. At least three phenotypic characters separate taxon 33 from other existing genera containing avian taxa. Separation from possible candidates for new genera containing avian taxa, including Pasteurella sensu stricto of cluster 18 (Olsen et al., 2004), [Haemophilus] paragallinarum and the taxon 2 and 3 complex of Bisgaard, has to await separate investigations.

\section{$16 S$ rRNA gene sequence comparison}

Six strains were selected for $16 \mathrm{~S}$ rRNA gene sequencing (Table 3). PCR amplification was performed as described by Vogel et al. (1997). Oligonucleotides for both PCR amplification and sequencing were synthesized according to sequences and 16S rRNA positions given by Dewhirst et al. (1989) and Paster \& Dewhirst (1988). PCR-amplified fragments were purified on Microspin columns (Pharmacia Biotech) and cycle-sequenced (Thermo Sequenase fluorescentlabelled primer cycle-sequencing kit; Amersham) on an ALF sequencer (Pharmacia Biotech) using fluoresceinlabelled primers.

Sequences of between 1434 and 1468 bp were obtained. The accession numbers for the strains are listed in Table 3. Searches for $16 \mathrm{~S}$ rRNA sequences were performed by FASTA and BLAST by use of the Wisconsin sequence analysis package (GCG, Madison). Pairwise comparisons for similarity were performed by BESTFIT (GCG). The four strains Gerl. $236 / 81^{\mathrm{T}}, 94,101$ and 103 of biovar 1 showed $99 \cdot 2-99 \cdot 9 \%$ similarity, whereas the two strains B96/5 and $146 / \mathrm{S} 8 / 89^{\mathrm{T}}$ of biovar 2 showed $99.9 \%$ 16S rRNA similarity. The lowest 
Table 2. Phenotypic characters that allow separation of Volucribacter gen. nov. from other accepted genera of the family Pasteurellaceae

Genera: 1, Mannheimia; 2, Actinobacillus sensu stricto; 3, Pasteurella sensu stricto cluster 12; 4, Pasteurella sensu stricto cluster 18; 5, Lonepinella; 6, Phocoenobacter, 7, Haemophilus sensu stricto (H. influenzae, H. haemolyticus and H. aegyptius); 8, Gallibacterium; 9, Histophilus; 10, Volucribacter gen. nov. Characters are scored as in Table 1; w, weakly positive; ND, no data.

\begin{tabular}{|c|c|c|c|c|c|c|c|c|c|c|}
\hline Character & 1 & 2 & 3 & 4 & 5 & 6 & 7 & 8 & 9 & 10 \\
\hline Methyl red $\left(37^{\circ} \mathrm{C}\right)$ & - & - & - & - & - & ND & $\mathrm{ND}$ & $\mathrm{w}$ & $\mathrm{ND}$ & + \\
\hline Urease & - & + & $-{ }^{c}$ & - & - & - & + & - & - & - \\
\hline Ornithine decarboxylase & $\mathrm{d}$ & - & $\mathrm{d}$ & $-^{d}$ & - & - & $\mathrm{d}$ & - & - & - \\
\hline Indole & - & - & + & - & - & - & $\mathrm{d}$ & - & + & - \\
\hline \multicolumn{11}{|l|}{ Acid production from: } \\
\hline Dulcitol & - & - & $\mathrm{d}$ & - & + & - & - & - & ND & - \\
\hline (-)-D-Mannitol & + & $+^{e}$ & $\mathrm{~d}$ & $\mathrm{~d}$ & - & - & - & + & $\mathrm{ND}$ & - \\
\hline$(+)$-D-Galactose & + & + & + & + & + & - & + & + & - & $+/(+)$ \\
\hline$(+)$-D-Glucose (with gas) & - & - & - & - & - & ND & $\mathrm{d}$ & - & ND & - \\
\hline$\alpha$-Glucosidase (PNPG) & - & $\mathrm{d}$ & + & + & - & ND & - & + & $\mathrm{ND}$ & - \\
\hline
\end{tabular}

${ }^{*}$ Variable results are indicated by: $a$, Actinobacillus pleuropneumoniae biovar 1 positive; $b$, Pasteurella gallinarum negative; $c$, Pasteurella dagmatis positive; $d$, Pasteurella volantium might be positive; $e$, Actinobacillus suis negative.

similarity observed between biovar 1 and 2 strains was $98 \cdot 8 \%$, between strains 94 and B96/5, while the highest similarity $(99 \cdot 5 \%)$ was observed between strains 103 and $146 / S 8 / 89^{\mathrm{T}}$. Strain Gerl. 236/81 ${ }^{\mathrm{T}}$ showed $99 \cdot 2-99 \cdot 9 \%$ similarity to biovar 1 strains and $99 \cdot 4 \%$ similarity to biovar 2 strains. Such high $16 \mathrm{~S}$ rRNA similarity between species is not unusual for members of the Pasteurellaceae, where 16S rRNA similarities of $99 \cdot 7 \%$ between type strains of Pasteurella gallinarum and Pasteurella volantium, as well as between Actinobacillus lignieresii and Actinobacillus pleuropneumoniae, corresponded to $72 \%$ DNA reassociation (Pohl et al., 1983; Mutters et al., 1985), and 99.6\% $16 \mathrm{~S}$ rRNA similarity between the type strains of Actinobacillus suis and Actinobacillus equuli corresponded to $66 \%$ DNA reassociation (Christensen et al., 2002a). The highest $16 \mathrm{~S}$ rRNA similarity outside the genus Volucribacter was found to the type stain of Pasteurella avium (accession no. M75058; 94.5\%) for strain 101 and to strain 69 of Bisgaard taxon 34 (accession no. AY172731; 94.6\% similarity) for strain 94 .

Table 3. Strains of Volucribacter gen. nov. investigated by $16 \mathrm{~S}$ rRNA gene sequence comparison

\begin{tabular}{|c|c|c|c|c|c|}
\hline Strain & Source ${ }^{*}$ & Country & $\begin{array}{l}\text { Organ of } \\
\text { isolation }\end{array}$ & Lesion & $\begin{array}{l}\text { 16S rRNA gene } \\
\text { accession no. }\end{array}$ \\
\hline \multicolumn{6}{|l|}{$V \cdot$ psittacicida (biovar 1) } \\
\hline 101 & African grey parrot & Germany & Salivary gland & Purulent inflammation & AF487723 \\
\hline 94 & Fischer's love bird & Germany & Lung & Pneumonia & AF487722 \\
\hline \multicolumn{6}{|l|}{ V. amazonae (biovar 2) } \\
\hline $\begin{array}{l}146 / \mathrm{S} 8 / 89^{\mathrm{T}}\left(=\text { CCUG } 47537^{\mathrm{T}}=\right. \\
\left.\text { DSM } 15535^{\mathrm{T}}\right)\end{array}$ & African grey parrot & Germany & Liver, heart & Septicaemia & AY216869 \\
\hline $\mathrm{B} 96 / 5$ & Parakeet & Belgium & No information & No information & AY216870 \\
\hline
\end{tabular}

${ }^{\star}$ African grey parrot (Psittacus erithacus), Fischer's love bird (Agapornis fischeri) and budgerigar (Melopsittacus undulatus) (Bisgaard et al., 1999). 


\section{Phylogenetic analysis}

The alignment was constructed by PILEUP (GCG) and included the region between Escherichia coli positions 64 and 1391 of $r r n B$, with 1283 positions left after removal of ambiguous positions and 184 distinct data patterns analysed. The alignment was in accordance with the secondary structure mask of Lane (1991). Maximumlikelihood analysis including bootstrap analysis was performed by fastDNAmL (Olsen et al., 1994) run on a Linux 7.2-compatible server with a transition/transversion ratio of $1 \cdot 5$. Parsimony and neighbour-joining analysis were performed by PHYLIP (Felsenstein, 1995).

The high 16S rRNA gene sequence similarity between the strains of taxon 33 proposed as Volucribacter was reflected in the phylogenetic comparison, where the representatives of the taxon formed a distinct monophyletic group supported by a bootstrap value of $99 \%$ (Fig. 1). The phylogenetic analysis shown in Fig. 1 was based on 16S rRNA gene sequences of type strains of the genera of Pasteurellaceae. The topology shown in Fig. 1 was identical when data were analysed by maximum-parsimony and neighbourjoining analysis. The distinct phylogenetic position of Volucribacter (Bisgaard taxon 33) with reference to all members of the family Pasteurellaceae has been shown previously (Christensen et al., 2003b). The genus was related to representatives of other members of the 'avian' cluster (Olsen et al., 2004), including members of Pasteurella sensu stricto (Mutters et al., 1989) isolated from birds, the new genus Gallibacterium (Christensen et al., 2003a), [Haemophilus] paragallinarum and taxa 2, 3 and 34 of Bisgaard (Christensen et al., 2003b). In conclusion, the

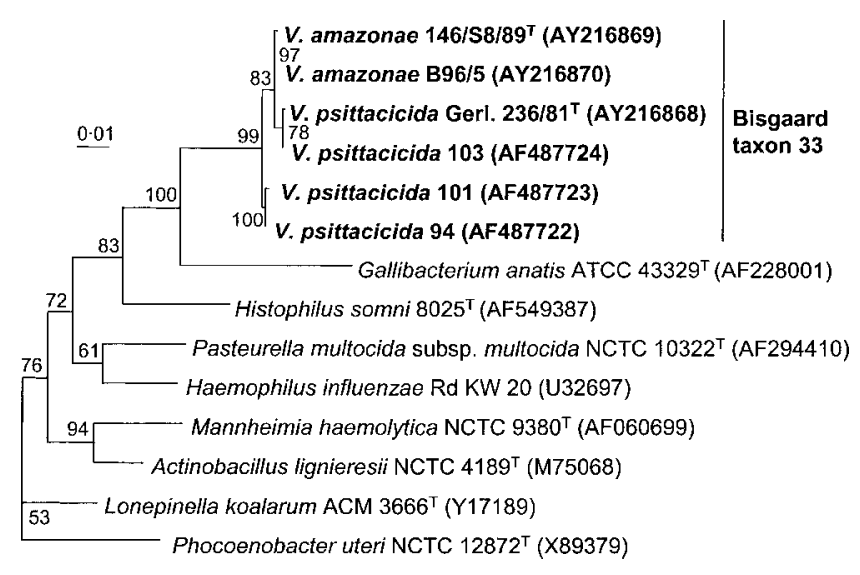

Fig. 1. Phylogenetic relationships between the taxa of Pasteurellaceae based on maximum-likelihood analysis of $16 \mathrm{~S}$ rRNA sequences with special regard to the newly proposed genus Volucribacter and members of type species of genera of Pasteurellaceae. Support for monophyletic groups by bootstrap analysis is indicated as percentages. Branch lengths have been drawn according to the scale bar (evolutionary distance), which is related to the number of nucleotide substitutions between the sequences and the time since the taxa diverged. proposed genus Volucribacter was unrelated to representatives of type species and $16 \mathrm{~S}$ rRNA clusters (Olsen et al., 2004) of Pasteurellaceae.

\section{DNA-DNA hybridizations}

DNA-DNA hybridizations were performed according to the microwell method described by Christensen et al. (2000). The DNA reassociation between strains Gerl. $236 / 81^{\mathrm{T}}$ and 101 of biovar 1 was $94 \%$ (Table 4). DNA reassociation between strain Gerl. $236 / 81^{\mathrm{T}}$ from biovar 1 and $146 / S 8 / 89^{\mathrm{T}}$ from biovar 2 was only $47 \%$, underlining the presence of two species. The DNA reassociation results published by Piechulla et al. (1985) were at most $24 \%$ to other taxa investigated, as observed between Gerl. 236/81 ${ }^{\mathrm{T}}$ and three strains of taxa 2 and 3 of Bisgaard. Only $6 \%$ DNA reassociation was found between Gerl. $236 / 81^{\mathrm{T}}$ and the type strain of Pasteurella gallinarum. A value of $70 \%$ DNA reassociation between strain Gerl. $236 / 81^{\mathrm{T}}$ and strain Gerlach 3348/80 (=F 219) of Gallibacterium was observed by Piechulla et al. (1985). This result was subsequently reinvestigated and found to be only $11 \%$ (Christensen et al., 2003a). A value of $76 \%$ DNA reassociation was found between Gerl. 236/81 ${ }^{\mathrm{T}}$ and a V-factor-requiring strain, Sittich 1, obtained from a parakeet (Piechulla et al., 1985). Further information is unfortunately not available for this strain. A group of Pasteurella avium-like organisms obtained from the respiratory tract of psittacine birds was reported by Beichel (1986). The single isolate (103) included in the present investigation and meeting the phenotypic characters of taxon 33 showed DNA reassociation values between 24 and $30 \%$ with Pasteurella multocida, Pasteurella stomatis, Pasteurella avium and Gallibacterium anatis and between 18 and $44 \%$ with Bisgaard taxon 16 (Stenzel, 1992).

The name Volucribacter gen. nov. is suggested for taxon 33, since the strains were isolated exclusively from birds. The names Volucribacter psittacicida sp. nov. and Volucribacter amazonae sp. nov. are suggested with reference to the hosts being members of the Psittaciformes. The strains of the new genus investigated all (except one) originated from psittacine birds, in which they were almost all associated with pathological conditions. Further studies are required,

Table 4. DNA-DNA hybridization results obtained with strains of Volucribacter gen. nov.

DNA from test strains was hybridized with DNA from strain Gerl. $236 / 81^{\mathrm{T}}$ (biovar 1). Numbers in parentheses are SD $(n=8)$.

\begin{tabular}{|lc|}
\hline Strain & $\begin{array}{c}\text { DNA-DNA } \\
\text { relatedness }(\%)\end{array}$ \\
\hline Biovar 1, strain 101 & $94(17)$ \\
Biovar 2, strain $146 / \mathrm{S} 8 / 89^{\mathrm{T}}$ & $47(9)$ \\
Gallibacterium genomospecies 1, strain CCM & $9(9)$ \\
5974 & \\
Gallibacterium anatis, strain Gerlach 3348/80 & $10(12)$ \\
\hline
\end{tabular}


however, in order to elucidate the host relations and pathogenicity of this genus.

\section{Description of Volucribacter gen. nov.}

Volucribacter (Vo.lu.cri.bac'ter. L. fem. n. volucris bird; N.L. masc. n. bacter rod; N.L. masc. n. Volucribacter rod-shaped bacterium of birds).

Gram-negative rods forming surface colonies on blood agar that are circular and slightly raised with an entire margin. The surface of the colonies is smooth, shiny and opaque with a greyish tinge. Colonies are $1.0-1.5 \mathrm{~mm}$ in diameter after aerobic incubation at $37^{\circ} \mathrm{C}$ for $24 \mathrm{~h}$. After incubation for $48 \mathrm{~h}$, a diameter of $2.0 \mathrm{~mm}$ might be reached. The consistency is buttery and colonies do not adhere to the agar surface. Growth on bovine blood agar is not accompanied by haemolysis. A greenish colour is sometimes associated with heavy growth. (+)-D-Glucose is catabolized fermentatively in Hugh and Leifson's medium and porphyrin, methyl red $\left(37^{\circ} \mathrm{C}\right)$, nitrate reduction and alanine aminopeptidase tests are positive within 1-2 days. (-)-D-Fructose, $(+)$-Dglucose, $(+)$-D-mannose and sucrose are fermented within 1-2 days, while (-)-D-ribose, $(+)$-D-galactose and raffinose are positive after 3 or more days. The phosphatase test is positive, but weak reactions might occur. Within 14 days of incubation, motility at 37 and $22^{\circ} \mathrm{C}$ is negative, and tests for symbiotic growth, growth on Simmons' citrate, malonate base, $\mathrm{H}_{2} \mathrm{~S}$ formation in TSI, $\mathrm{KCN}$ growth, VogesProskauer at $37^{\circ} \mathrm{C}$, gas from nitrate, urease, arginine dihydrolase, lysine decarboxylase, ornithine decarboxylase, phenylalanine deaminase, indole formation, gelatinase, hydrolysis of Tween 20 or 80 , MacConkey growth, pigment, formation of gas from ( + )-D-glucose, $\alpha$-fucosidase, $\alpha$-glucosidase, $\beta$-glucuronidase, $\alpha$-mannosidase and $\beta$ xylosidase are all negative. Acid is not formed from mucate, meso-erythritol, adonitol, (+)-D-arabitol, xylitol, (-)-L-xylose, dulcitol, (-)-D-mannitol, (-)-D-sorbitol, $(+)$-D-fucose, $(+)$-L-rhamnose, $(-)$-L-sorbose, trehalose, cellobiose, (+)-D-melezitose, (+)-D-glycogen, inulin, aesculin, amygdalin, arbutin, gentiobiose, salicin, (+)-Dturanose or $N$-methyl $\beta$-glucosamide. Variable characters include catalase, oxidase, glycerol, ( + )-L-arabinose, $(-)$-Darabinose, (+)-D-xylose, meso-inositol, (-)-L-fucose, lactose, ONPG, maltose, (+)-D-melibiose, dextrin and $\alpha$-galactosidase. The bacteria have been isolated from parrots, budgerigars, parakeets and a chicken, mainly showing respiratory tract or septicaemic lesions. The type species is Volucribacter psittacicida.

\section{Description of Volucribacter psittacicida sp. nov.}

Volucribacter psittacicida (psit.ta.ci'ci.da. L. masc. n. psittacus the parrot; L. masc./fem. suffix n. -cida killer; N.L. masc. n. psittacicida killer of parrots).

Colony and cellular morphology and phenotypic reactions are identical to those given in the genus description. In addition, the species is positive or weakly positive in reactions for phosphatase. Late positive reactions are observed with glycerol, while negative reactions are observed with $(+)$-L-arabinose, (-)-D-arabinose, (+)-D-xylose, mesoinositol, (-)-L-fucose, lactose, maltose, (+)-D-melibiose, dextrin, $\alpha$-galactosidase and ONPG. Variable reactions are observed for catalase and oxidase. The species can be separated from $V$. amazonae by the lack of fermentation of meso-inositol, (-)-L-fucose, maltose and dextrin and the negative ONGP reaction. Plasmids were not found in the type strain (procedure reported by Christensen et al., 2003a).

The type strain is Gerl. $236 / 81^{\mathrm{T}}$ (=CCUG $47536^{\mathrm{T}}=$ DSM $\left.15534^{\mathrm{T}}\right)$, obtained from a parakeet with septicaemia and received from H. Gerlach, Munich, Germany, in 1981. The characterization was based on 22 strains from three different countries representing isolates mostly obtained from lesions in parrots, budgerigar, parakeets and a chicken. The DNA G + C content of strain 103 was $39.9 \mathrm{~mol} \%$, while the genome mass was $1.4 \times 10^{9} \mathrm{Da}$ (Stenzel, 1992). The $\mathrm{G}+\mathrm{C}$ content of strain Gerl. $236 / 81^{\mathrm{T}}$ was $40 \cdot 8 \mathrm{~mol} \%$ and the genome mass $2 \cdot 4 \times 10^{9} \mathrm{Da}$ (Piechulla et al., 1985).

\section{Description of Volucribacter amazonae sp. nov.}

Volucribacter amazonae (a.ma.zo.na'e. N.L. gen. sing. n. amazonae of parrots of the genus Amazona).

Colony and cellular morphology and other phenotypic reactions are identical to those given in the genus description; in addition, the species is positive for catalase, phosphatase and ONPG and ferments meso-inositol, (-)-Lfucose, maltose and dextrin. Variable reactions are observed for production of acid from glycerol, (+)-L-arabinose, $(-)$ D-arabinose, $(+)$-D-xylose, lactose and $(+)$-D-melibiose and the $\alpha$-galactosidase test. The species can be separated from $V$. psittacicida by fermentation of meso-inositol, (-)L-fucose, maltose and dextrin and positive reaction for ONPG.

Three strains of the species isolated from parrots and parakeet have been characterized. The type strain, 146/S8/ $89^{\mathrm{T}}\left(=\right.$ CCUG $47537^{\mathrm{T}}=$ DSM $\left.15535^{\mathrm{T}}\right)$, was originally isolated from an African grey parrot (Psittacus erithacus) with septicaemia by H. Gerlach, Munich, Germany, in 1989.

\section{Acknowledgements}

Pia Mortensen, Pia Katrine Nielsen and Kristian Petersen are thanked for excellent technical assistance. Professor H. G. Trüper, Department of Microbiology, Universität Bonn, and Dr J. P. M. Euzéby, National Veterinary School of Toulouse, are thanked for careful help with the Latin names. This project was financed by the Danish Agricultural and Veterinary Research Council grant number 9702797.

\section{References}

Angen, Ø., Mutters, R., Caugant, D. A., Olsen, J. E. \& Bisgaard, M. (1999). Taxonomic relationships of the [Pasteurella] haemolytica 
complex as evaluated by DNA-DNA hybridizations and 16S rRNA sequencing with proposal of Mannheimia haemolytica gen. nov., comb. nov., Mannheimia granulomatis comb. nov., Mannheimia glucosida sp. nov., Mannheimia ruminalis sp. nov. and Mannheimia varigena sp. nov. Int J Syst Bacteriol 49, 67-86.

Angen, Ø., Ahrens, P., Kuhnert, P., Christensen, H. \& Mutters, R. (2003). Proposal of Histophilus somni gen. nov., sp. nov. for the three species incertae sedis 'Haemophilus somnus', 'Haemophilus agni' and 'Histophilus ovis'. Int J Syst Evol Microbiol 53, 1449-1456.

Beichel, E. (1986). Differenzierung von $130 X$ - und V-Faktorunabhängigen aviären Bakteriestämmen der Familie Pasteurellaceae Pohl 1981 unter besonderer berücksichtigung neuer taxonomischer Erkentnisse. Inaugural-Dissertation, Tierärtliche Hochschule Hannover, Germany (in German).

Bisgaard, M. (1993). Ecology and significance of Pasteurellaceae in animals. Zentbl Bakteriol 279, 7-26.

Bisgaard, M., Houghton, S. B., Mutters, R. \& Stenzel, A. (1991). Reclassification of German, British and Dutch isolates of so-called Pasteurella multocida obtained from pneumonic calf lungs. Vet Microbiol 26, 115-124.

Bisgaard, M., Hinz, K.-H., Petersen, K. D. \& Christensen, J. P. (1999). Identification of members of the Pasteurellaceae isolated from birds and characterization of two new taxa isolated from psittacine birds. Avian Pathol 28, 369-377.

Christensen, H. \& Bisgaard, M. (2004). Revised definition of Actinobacillus sensu stricto isolated from animals. A review with special emphasis on diagnosis. Vet Microbiol 99, 13-30.

Christensen, H., Angen, Ø., Mutters, R., Olsen, J. E. \& Bisgaard, M. (2000). DNA-DNA hybridization determined in micro-wells utilizing covalent attachment of DNA. Int J Syst Evol Microbiol 50, 1095-1102.

Christensen, H., Bisgaard, M. \& Olsen, J. E. (2002a). Reclassification of equine isolates previously reported as Actinobacillus equuli, variants of A. equuli, Actinobacillus suis or Bisgaard taxon 11 and proposal of $A$. equuli subsp. equuli subsp. nov. and A. equuli subsp. haemolyticus subsp. nov. Int J Syst Evol Microbiol 52, 1569-1576.

Christensen, H., Dziva, F., Olsen, J. E. \& Bisgaard, M. (2002b). Genotypic heterogeneity of Pasteurella gallinarum as shown by ribotyping and 16S rRNA sequencing. Avian Pathol 31, 603-610.

Christensen, H., Bisgaard, M., Bojesen, A. M., Mutters, R. \& Olsen, J. E. (2003a). Genetic relationships among avian isolates classified as Pasteurella haemolytica, 'Actinobacillus salpingitidis' or Pasteurella anatis with proposal of Gallibacterium anatis gen. nov., comb. nov. and description of additional genomospecies within Gallibacterium gen. nov. Int J Syst Evol Microbiol 53, 275-287.

Christensen, H., Foster, G., Christensen, J. P., Pennycott, T., Olsen, J. E. \& Bisgaard, M. (2003b). Phylogenetic analysis by $16 \mathrm{~S}$ rDNA gene sequence comparison of avian taxa of Bisgaard and characterization and description of two new taxa of Pasteurellaceae. J Appl Microbiol 95, 354-363.

Dewhirst, F. E., Paster, B. J. \& Bright, P. L. (1989). Chromobacterium, Eikenella, Kingella, Neisseria, Simonsiella, and Vitreoscilla species comprise a major branch of the beta group Proteobacteria by $16 \mathrm{~S}$ ribosomal ribonucleic acid sequence comparison: transfer of Eikenella and Simonsiella to the family Neisseriaceae (emend.). Int J Syst Bacteriol 39, 258-266.

Felsenstein, J. (1995). PHYLIP (Phylogeny Inference Package) version 3.57c. Distributed by the author. Department of Genetics, University of Washington, Seattle, USA.
Foster, G. \& Collins, M. D. (2004). Genus Phocoenobacter Foster, Ross, Malnick, Willems, Hutson, Reid and Collins 2000, $138^{\mathrm{VP}}$. In Bergey's Manual of Systematic Bacteriology, 2nd edn, vol. 2. Edited by G. M. Garrity. New York: Springer (in press).

Kilian, M. (2004). Genus Haemophilus Winslow, Broadhurst, Buchanan, Krumwiede, Rogers and Smith 1917, 561 ${ }^{\mathrm{AL}}$. In Bergey's Manual of Systematic Bacteriology, 2nd edn, vol. 2. Edited by G. M. Garrity. New York: Springer (in press).

Lane, D. (1991). 16S/23S rRNA sequencing. In Nucleic Acid Techniques in Bacterial Systematics, pp. 115-147. Edited by E. Stackebrandt \& M. Goodfellow. New York: Wiley.

Mutters, R., Piechulla, K., Hinz, K.-H. \& Mannheim, W. (1985). Pasteurella avium (Hinz and Kunjara 1977) comb. nov. and Pasteurella volantium sp. nov. Int J Syst Bacteriol 35, 5-9.

Mutters, R., Mannheim, W. \& Bisgaard, M. (1989). Taxonomy of the group. In Pasteurella and Pasteurellosis, pp. 3-34. Edited by C. Adlam \& J. M. Rutter. London: Academic Press.

Mutters, R., Christensen, H. \& Bisgaard, M. (2004). Genus Pasteurella Trevisan 1887, $94^{\mathrm{AL}}$ nom. cons. Opin. 13, Jud. Comm. 1954. In Bergey's Manual of Systematic Bacteriology, 2nd edn, vol. 2. Edited by G. M. Garrity. New York: Springer (in press).

Olsen, G. J., Matsuda, H., Hagström, R. \& Overbeek, R. (1994). fastDNAmL: a tool for construction of phylogenetic trees of DNA sequences using maximum likelihood. Comput Appl Biosci 10, 41-48.

Olsen, I., Dewhirst, F. E., Paster, B. J. \& Busse, H.-J. (2004) Family Pasteurellaceae. In Bergey's Manual of Systematic Bacteriology, 2nd edn, vol. 2. Edited by G. M. Garrity. New York: Springer (in press).

Osawa, R. \& Stackebrandt, E. (2004). Genus Lonepinella Osawa, Rainey, Fujisawa, Lang, Busse, Walsh and Stackebrandt 1996, $362^{\mathrm{VP}}$ (effective publication: Osawa, Rainey, Fujisawa, Land, Busse, Walsh and Stackebrandt 1995, 372). In Bergey's Manual of Systematic Bacteriology, 2nd edn, vol. 2. Edited by G. M. Garrity. New York: Springer (in press).

Paster, B. J. \& Dewhirst, F. E. (1988). Phylogeny of campylobacters, wolinellas, Bacteroides gracilis, and Bacteroides ureolyticus by $16 \mathrm{~S}$ ribosomal ribonucleic acid sequencing. Int $J$ Syst Bacteriol $\mathbf{3 8}$, 56-62.

Piechulla, K., Bisgaard, M., Gerlach, H. \& Mannheim, W. (1985). Taxonomy of some recently described avian Pasteurellal Actinobacillus-like organisms as indicated by deoxyribonucleic acid relatedness. Avian Pathol 14, 281-311.

Pohl, S., Bertschinger, H. U., Frederiksen, W. \& Mannheim, W. (1983). Transfer of Haemophilus pleuropneumoniae and the Pasteurella haemolytica-like organism causing porcine necrotic pleuropneumonia to the genus Actinobacillus (Actinobacillus pleuropneumoniae comb. nov.) on the basis of phenotypic and deoxyribonucleic acid relatedness. Int J Syst Bacteriol 33, 510-514.

Stenzel, A. (1992). Untersuchnungen zur Taxonomie atypischer Pasteurella und Pasteurella-ähnlicher Bakterien-stamme: DNA:DNAhybridisierung und phenotüpische Characterisierung. InauguralDissertation der Philipps-Universität, Marburg, Germany (in German).

Vogel, B. F., Jørgensen, K., Christensen, H., Olsen, J. E. \& Gram, L. (1997). Differentiation of Shewanella putrefaciens and Shewanella alga on the basis of whole-cell protein profiles, ribotyping, phenotypic characterization, and 16S rRNA gene sequence analysis. Appl Environ Microbiol 63, 2189-2199. 